\title{
Very Rare Salivary Gland Tumor: Follicular Variant of Acinic Cell Carcinoma
}

\author{
Betül Demirciler Yavaş, ${ }^{1}$ Orhan Kemal Kahveci, ${ }^{2}$ Esra Uygur, ${ }^{1}$ Emre Kaçar, ${ }^{3}$ Çiğdem Tokyol
}

\author{
'Department of Pathology, \\ Afyon Kocatepe University \\ Faculty of Medicine, \\ ${ }^{2}$ Department of \\ Otorhinolaryngology \\ Afyon Kocatepe University \\ Faculty of Medicine \\ ${ }^{3}$ Department of Radiology, Afyon \\ Kocatepe University Faculty of \\ Medicine; all Afyonkarahisar, Turkey \\ Submitted: 22.04.2016 \\ Accepted: 08.08.2016 \\ Correspondence: \\ Betül Demirciler Yavas, \\ Afyon Kocatepe Üniversitesi Tıp \\ Fakültesi, B Blok, Patoloji Anabilim \\ Dalı, Afyonkarahisar, Turkey \\ E-mail: betuldy@gmail.com

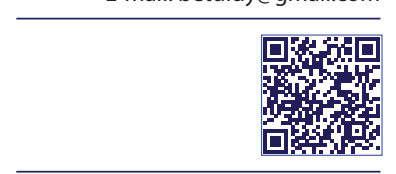 \\ Keywords: Acinic cell \\ carcinoma; follicular; \\ salivary gland.
}

\begin{abstract}
Acinic cell carcinomas are very rare tumors. Patients seek medical advice usually for solitary mass in parotid or facial location. They are generally slow-growing, low malignant potential tumors and they usually have long survival periods. Surgical excision is adequate for treatment. Our case is follicular variant of acinic cell carcinoma which is the rarest histological form of this tumor. It is very important to consider normal salivary gland and most other tumors in the differential diagnosis.
\end{abstract}

\section{INTRODUCTION}

Acinic cell carcinomas are very rare tumors. Salivary gland tumors constitute only $3 \%$ of the all head-andneck tumors. ${ }^{[l-3]}$ Acinic cell carcinoma (ACC) constitutes $6 \%$ of the salivary gland tumors and $3-13 \%$ of the malign tumors. ${ }^{[4-6]}$ These tumors are thought to be originated either from terminal duct or serous acinar cells. [7] The most frequent localization is seen in the parotis and it is more seen in women. ${ }^{[8]}$ Although this disease is usually seen in fifth and sixth decades, it has also been reported in all age groups including childhood. ${ }^{[5,6,9]}$ Histopathologically, there are solid, micro-cystic, papillarycystic, follicular variants of this tumor; it might also be seen in a mixed pattern. ${ }^{[4]}$ When these tumors have a mixed pattern, they are classified according to the most common pattern. Acinic cell carcinomas usually grow slowly. The rarest pattern is follicular pattern. ${ }^{[4]}$ Acinic cell carcinoma is a slow-growing tumor and their malignity capacity is very low. Recurrence is reported in a few cases. Lymph node or distant metastases are very rare, too. ${ }^{[0]}$

\section{CASE REPORT}

A 46-year-old female patient visited our clinic with a swelling behind her left ear which was present for two months. She did not have any complaints like pain, fever or mouth dryness except feeling of this mass. A soft and mobile mass which is almost in a $2-\mathrm{cm}$ diameter 
was palped in her examination (Figure la). This mass was reported as benign according to needle aspiration biopsy. In her neck compute tomography, a nodular lesion $2 \mathrm{~cm}$ in diameter contrasted in homogeneous density which has focally micronodular borders was observed (Figure Ib) and histopathologic examination was suggested. Left superficial parotidectomy surgery was applied to the patient. In the surgery, it was observed that the mass was limited in the superficial lobe and no connection was seen with the facial nerve. The surgery was ended by preserving facial nerve branches. In the first week and first month follow-ups, any recurrence was not seen and facial nerve functions were normal. Macroscopically, the lesion was grey-yellow and evenly bounded and its sections were focally hemorrhagic. The mass was observed as $1.9 \times 1.7 \times 1.5 \mathrm{~cm}$ in size in a parotid gland which is $5.2 \times 3.5 \times 2.3 \mathrm{~cm}$ in size. In the hematoxylin-eosin (H\&E) sections, a lesion composed of microcystic and follicular structures with luminal secretion which was separated with sharp borders from salivary gland tissue is observed (Figure 2a, b). The cells inlaying these follicular and mictocystic structures were uniform and did not contain atypia or mitosis. Most of the cells were polygonal-shaped and had dark basophilic, granular cytoplasm; others were narrower and cuboidal and they had amphophilic cytoplasm (Figure 3). Immunohistochemically, it was stained positive with CK7 (Keratin 7 Ab-2 Mouse Monoclonal, MS-1352, Thermo scientific, I/300 dilution) (Figure 4a), $\beta$-catenin (Catenin beta, Rabbit Polyclonal, RB-9035, Thermo scientific, I/400 dilution) (Figure 4b) and Cyclin DI (Cyclin DI SP-4, Rabbit Monoclonal, RM-9104, Thermo scientific, I/50 dilution) (Figure 4c), its proliferation index was detected as 3\% with Ki67 (Ki67, Rabbit Monoclonal, RM-
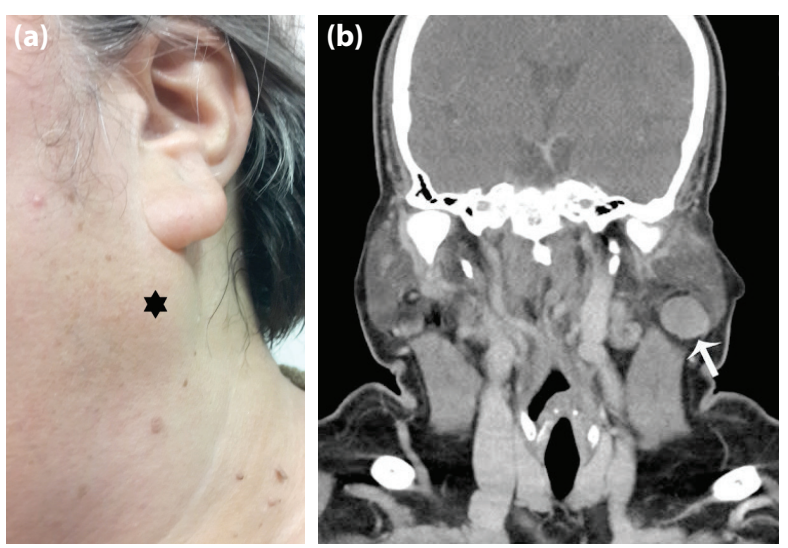

Figure 1. (a) A mass in 2-cm diameter in the left parotid lobe (star). (b) A nodular occupant lesion in the inferior area of the left parotid gland contrasted at a homogenous density.
9106, Thermo scientific, 1/300 dilution) (Figure 4d). By taking these results into account, the case was diagno-

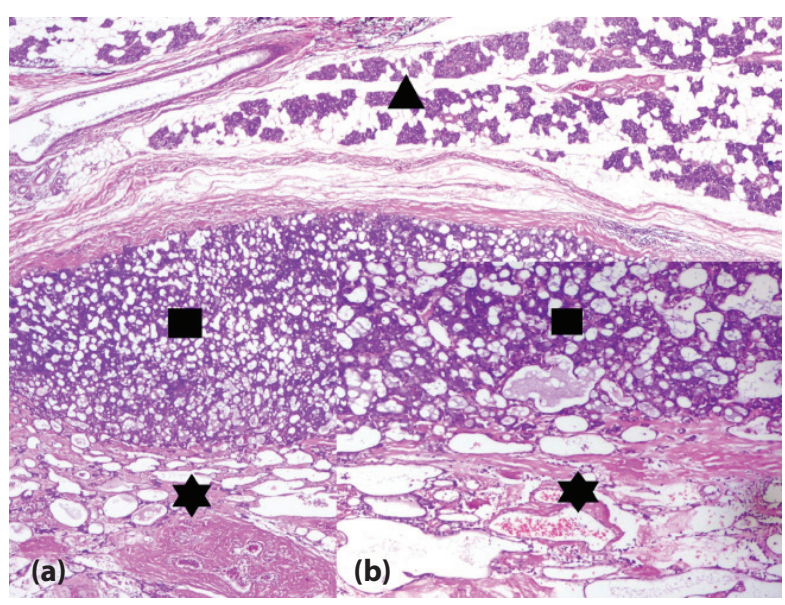

Figure 2. (a, b) Lesions which were formed from microcystic (square) and follicular (star) structures isolated with a uniform border from salivary gland tissue (triangle), had secretions in the lumens of some cells. ([a]: $x 40 \mathrm{H} \& \mathrm{E},[\mathrm{b}]:$ x100 H\&E).

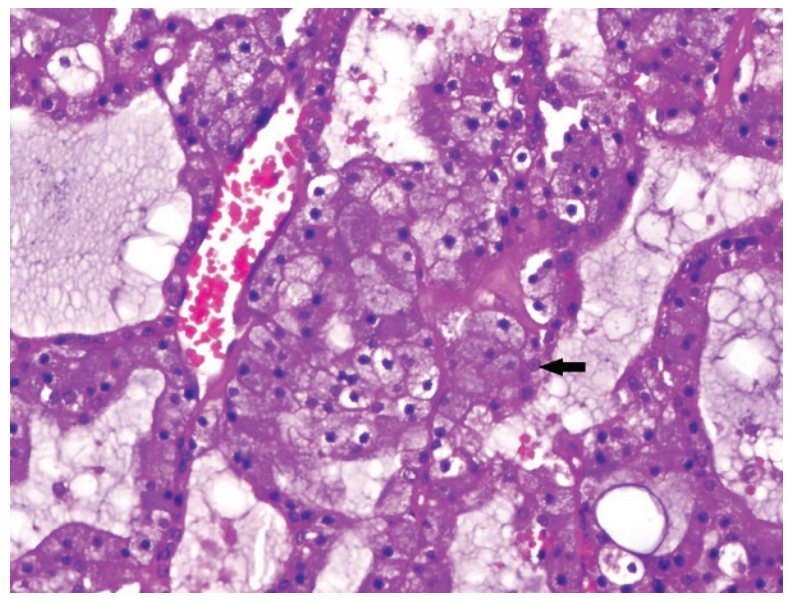

Figure 3. Polygonal-shaped cells with dark basophilic, granular cytoplasm (x200 H\&E).
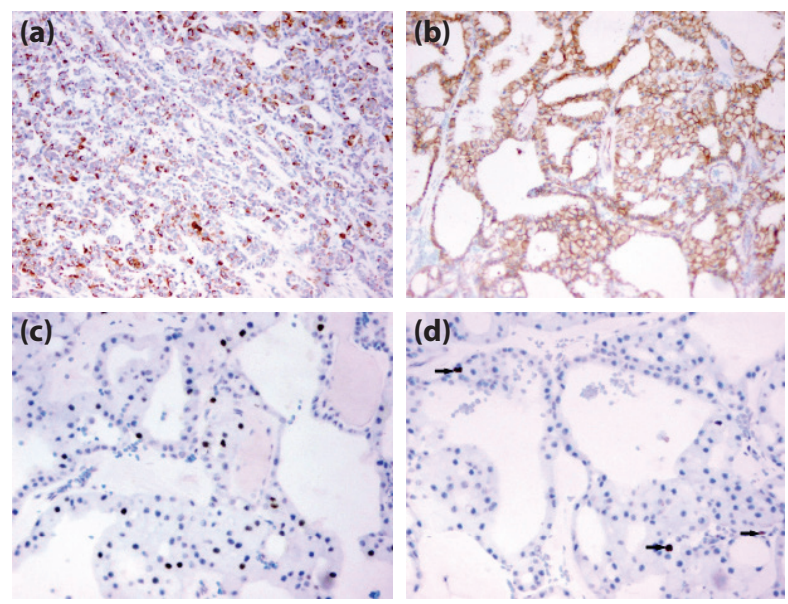

Figure 4. Immunohistochemical dyes. (a) x100 CK7, (b) x200 $\beta$-catenin, (c) x200 Cyclin-D1, (d) x200 Ki67. 
sed as follicular dominant mixed (follicular-microcystic) acinic cell carcinoma.

\section{DISCUSSION}

Patients with acinic cell carcinoma usually visit hospital with a mobile mass in parotid or facial location. The formation process may take weeks or a few decades. Pain complaint is generally seen half of the patients. Facial nerve paralysis is seen only in $5-10 \%$ of the cases. ${ }^{[4]}$ In our case, no pain or facial nerve paralysis was reported. She visited hospital with a painless mass which emerged in two months in parotis gland localisation.

Acinic cell carcinomas localize most frequently in parotid gland. Second frequently, they are seen in minor salivary gland or less frequently in the submandibular and sublingual glands. ${ }^{[4]}$ In most of the cases, they are fine-bordered, solitary, oval masses. Its sections are usually tan colored and it contains cystic hemorrhagic areas. $^{[4]}$ Microscopically, there are four variants of it such as solid, microcystic, papillary-cystic and follicular. Tumor might be composed of either several or only a solitary pattern. The least frequent pattern is follicular pattern with $5 \%$ occurrence. They are classified according to the most common pattern. ${ }^{[4, I I]}$ Tumor-forming cells can be serous acinar, 'intercalated' ductal, vacuolar, non-specific glandular or transparent type. Almost all tumors localized in the parotid gland are composed of serous-type acinar cells. ${ }^{[4]}$ In cytological examinations, it can easily confuse with benign lesions especially in cystic lesions. ${ }^{[12,13]}$ Our case was formed with more serous acinar and less 'intercalated' ductal type cells and it has a mixed pattern with $60 \%$ follicular and $40 \%$ microcytic areas. Since it has a fine-bordered, is composed of uniform cells and have $3 \% \mathrm{Ki} 67$ index without mitosis or necrosis, it was evaluated as a histopathologically low grade tumor.

In very rare cases, acinic cell carcinoma can be high grade. These are more aggressive with respect to the classical types and recurrence, perineural and perilymphatic invasion and systemic metastases are observed more frequently. In these forms, necrosis in large areas, high mitotic rate and a high $\mathrm{Ki} 67$ proliferation index is observed.

According to CK7 staining results, it is classified under three groups. The ones that are formed with pure acinar cells are not stained with CK7, but the ones that are formed with pure ductal cells are stained with CK7 diffusely. 10-66\% staining was seen in the ductuloacinar ones. $^{\left[{ }^{[4]}\right]}$ In our case, $30 \%$ staining was observed with CK7.

In the differential diagnosis, since that kind of tumors can show a very different kinds of pattern, many malign and benign tumors and normal salivary gland might be considered ${ }^{[7]}$ In fine-needle aspiration biopsies, well differentiated ACCs can be confused with normal salivary gland. In normal salivary gland, the presence of adipocytes and lobular, ductal acinar structures and absence of stromal fibrosis provide us a chance to detect these tumors. ${ }^{[4]}$ The presence of mucin in both acinic cell carcinoma and mucoepidermoid carcinoma (MEC) can make it hard to distinguish them. Especially, ACC with a microcytic pattern can be mixed with mucoepidermoid carcinoma more easily. The absence of serous acinar cells in the mucoepidermoid carcinoma can provide a chance for distinctive diagnosis. Additionally, as P-63 is always positive in MEC, it is negative in $\mathrm{ACCs}{ }^{[4,15]} \mathrm{Pa}-$ pillary variant $A C C s$ can be mixed with tyroid papillary carcinoma and it can be distinguished with thyroglobulin staining. Papillary variant ACCs are thyroglobulin negative. Epitelial-myoepitelial car-cinoma, clear cell carcinoma, clear cell oncosytoma and metastatic renal cell carcinoma can be added to the differential diagnosis of the clear cell ACC..$^{[7]}$ The serous acinar differentiation is not found in epithelial-myoepithelial carcinoma. A severe fibrosis and high glycogen content is observed in clear cell carcinoma. There are not basophilic cytoplasmic granules in the clear cell oncocytoma, but there is glycogen and it gives a positive reaction with PTAH (phosphotungstic acid hematoxylin). In metastatic renal cell carcinoma, cells have a pseudo-alveolar pattern, well-defined intracellular borders, high glycogen content and pleomorphism. ${ }^{[4]}$ In our case, there is no clear cell component, but tumor tissue contains microcystic and follicular variants.

Acinic cell carcinoma has a good survival rate. Surgical excision is enough for treatment. Post-operative adjuvant therapy is needed for advanced cases and for the cases whose surgical border is not negative. ${ }^{[16]}$ In the early and low-level cases that are treated with both surgical and adjuvant radiotherapy, any positive effect of adjuvant therapy has not been reported for survival. [17] Since the tumor in our case is histopathologically low grade and it has intact borders, any additional treatment was not needed after surgery.

Consequently, several tumors considered in the differential diagnosis of ACC which has divergent histopathologic characteristics, have different prognosis and 
different treatment modalities. In the case of a low grade ACC, it is important to distinguish it from other tumors, because only surgical treatment is enough and the survival rate of ACC is longer than other tumor types.

\section{Conflict of interest}

None declared.

\section{REFERENCES}

1. Ateşpare A, Boyacı Z, Midi A. Acinic cell carcinoma of parotid gland. Maltepe Med J 2014;6:15-9.

2. Guzzo M, Locati LD, Prott FJ, Gatta G, McGurk M, Licitra L. Major and minor salivary gland tumors. Crit Rev Oncol Hematol 2010;74:134-48.

3. Boukheris H, Curtis RE, Land CE, Dores GM. Incidence of carcino$\mathrm{ma}$ of the major salivary glands according to the WHO classification, 1992 to 2006: a population-based study in the United States. Cancer Epidemiol Biomarkers Prev 2009;18:2899-906.

4. Thompson LDR, Wenig BM, Nelson BL, Müller S. Diagnostic Pathology Head and Neck. Amirsys; 2013. p. 82-9.

5. Şimşek G, Akın İ, Köybaşıŏlu F. Dedifferentiated Acinic Cell Carcinoma of Parotidandits Treatment:A Rare Case Report.J Turgut Ozal Med Cent 2015;22:113-6.

6. Kim SA, Mathog RH. Acinic cell carcinoma of the parotid gland: a 15-year review limited to a single surgeon at a single institution. Ear Nose Throat J 2005;84:597-602.

7. Sams RN, Gnepp DR. P63 expression can be used in differential diagnosis of salivary gland acinic cell and mucoepidermoid carcinomas. Head Neck Pathol 2013;7:64-8.
8. Al-Zaher N, Obeid A, Al-Salam S, Al-Kayyali BS. Acinic cell carcinoma of the salivary glands: a literature review. Hematol Oncol Stem Cell Ther 2009;2:259-64.

9. Orvidas LJ, Kasperbauer JL, Lewis JE, Olsen KD, Lesnick TG. Pediatric parotid masses. Arch Otolaryngol Head Neck Surg 2000;126:177-84.

10. Erkmen E, Ataç MS, Tokman B, Gülçiçek T. Acinic cell carcinoma of the cheek - Arising from minor salivary gland tissue: Case Report. GÜ Dişhek. Fak. Derg 2003;20:47-50.

11. Munteanu MC, Mărgăritescu C, Cionca L, Nițulescu NC, Dăguci L, Ciucă EM. Acinic cell carcinoma of the salivary glands: a retrospective clinicopathologic study of 12 cases. Rom J Morphol Embryol 2012;53:313-20.

12. Khan S, Pujani M, Hassan MJ, Jetley S. Papillary cystic variant of acinic cell carcinoma presenting as parotid tail tumor. Int J Appl Basic Med Res 2015;5:139-41.

13. Augustine J, Kumar P, Saran RK, Mohanty S. Papillary cystic acinic cell carcinoma: Report of a rare lesion with unusual presentation. J Clin Exp Dent 2011;3:169-171.

14. Schwarz S, Zenk J, Müller M, Ettl T, Wünsch PH, Hartmann A, et al. The many faces of acinic cell carcinomas of the salivary glands: a study of 40 cases relating histological and immunohistological subtypes to clinical parameters and prognosis. Histopathology 2012;61:395-408.

15. Gattuso P, Reddy V, David O, Spitz D, Haber M. Differantial diagnosis in surgical pathology. $3^{\text {rd }}$ ed. Saunders Elsevier; 2010. p. 161-3.

16. Lin WN, Huang HC, Wu CC, Liao CT, Chen IH, Kan CJ, et al. Analysis of acinic cell carcinoma of the parotid gland - 15 years experience. Acta Otolaryngol 2010;130:1406-10.

17. Andreoli MT, Andreoli SM, Shrime MG, Devaiah AK. Radiotherapy in parotid acinic cell carcinoma: does it have an impact on survival? Arch Otolaryngol Head Neck Surg 2012;138:463-6.

\section{Nadir Görülen Tükürük Bezi Tümörü: Folliküler Varyant Asinüs Hücreli Karsinom}

Asinüs hücreli karsinomlar oldukça nadir tümörlerdir. Hastalar parotis ya da fasiyal, soliter kitle şikayeti ile genellikle başvururlar. Genelde çok yavaş büyürler, malignite potansiyelleri oldukça düşüktür. Sağkalımı çok iyi bir tümördür. Cerrahi eksizyon tedavi için yeterlidir. Olgumuz en nadir görülen paterne sahip, folliküler varyant asinüs hücreli karsinomdur. Ayırıcı tanısının hem normal tükürük bezinden, hem de pek çok tümörden yapılması önemlidir.

Anahtar Sözcükler: Asinüs hücreli karsinom; folliküler; tükürük bezi. 